\title{
Saving Model Under Financial Literacy
}

\section{Muzafar Hussain Shah, Logasvathi Murugiah, Norzalina Binti Ahmad}

To Link this Article: http://dx.doi.org/10.6007/IJARBSS/v11-i1/8557

DOI:10.6007/IJARBSS/v11-i1/8557

Received: 10 November 2020, Revised: 12 December 2020, Accepted: 04 January 2021

Published Online: 26 January 2021

In-Text Citation: (Shah et al., 2021)

To Cite this Article: Shah, M. H., Murugiah, L., \& Ahmad, N. B. (2021). Saving Model Under Financial Literacy. International Journal of Academic Research in Business and Social Sciences, 11(1), 611-631.

\section{Copyright: (c) 2021 The Author(s)}

Published by Human Resource Management Academic Research Society (www.hrmars.com)

This article is published under the Creative Commons Attribution (CC BY 4.0) license. Anyone may reproduce, distribute, translate and create derivative works of this article (for both commercial and non-commercial purposes), subject to full attribution to the original publication and authors. The full terms of this license may be seen

at: http://creativecommons.org/licences/by/4.0/legalcode

Vol. 11, No. 1, 2021, Pg. 611 - 631

Full Terms \& Conditions of access and use can be found at http://hrmars.com/index.php/pages/detail/publication-ethics 


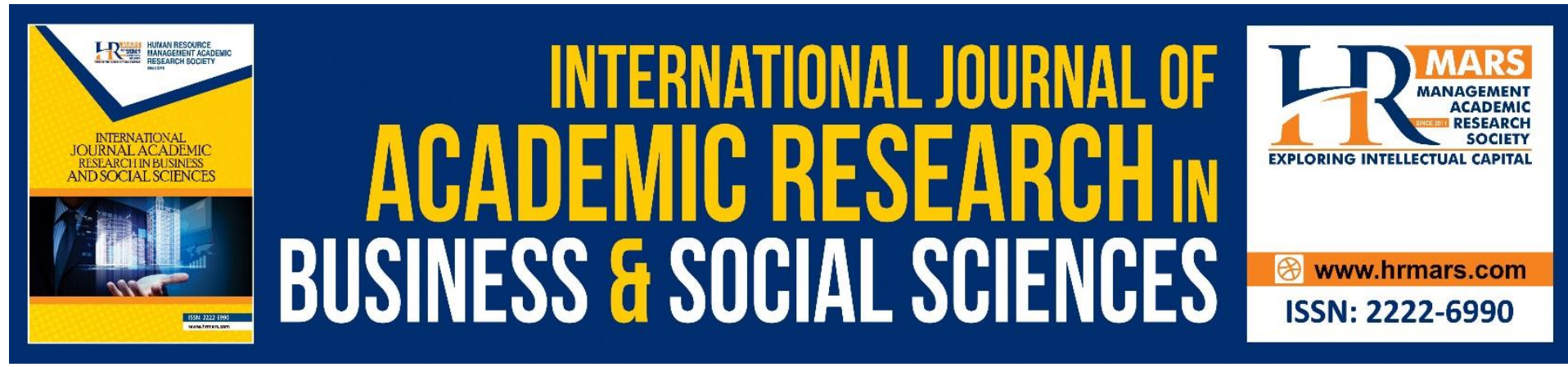

\title{
Saving Model Under Financial Literacy
}

\section{Muzafar Hussain Shah, Logasvathi Murugiah, Norzalina Binti Ahmad}

School of Economics Finance and Banking, College of Business, Universiti Utara Malaysia

Email: syedmuzafar110@gmail.com, logasvathi@uum.edu.my,norzalina@uum.edu.my

\begin{abstract}
The study attempted to assess how family background, and peer role affect the saving decisions of working youth in Pakistan. Current study also attempted to measure the effect of financial literacy as mediator between relationship of peer role and family back ground with saving decisions of working youth. Working youth among different organizations with total of 309 responses were collected through stratified random sampling. Using structural equation modeling through Smart PLS3, the study found that the significant effect of peer role on saving, and financial literacy. On other side family background shown insignificant effect on saving decisions but significant effect on financial literacy. Furthermore this study also found significant effect of financial literacy on saving decisions. Additionally this research shown mediated effect of family background and peer role on saving decisions through financial literacy. Findings of this study shaded the light that how family background, peer role have influenced saving decisions directly and indirectly through mediation by financial literacy. This research framework was tested under life cycle hypothesis and relative income hypothesis. Further policy makers could design policies and arranging training workshops for financial literacy awareness among working youth, as it is already highlighted that youth is also lacking in financial literacy (Bashir et al., 2013a; Arif, 2015; Bhabha et al., 2014).
\end{abstract}

Keywords: Family Background, Peer Role, Financial Literacy, Saving Decisions, Pakistan.

\section{Introduction}

Money on individual part play important role in life of individuals. Every person needs money to buy things, which they need and desire. Without proper money management, the person can face financial difficulties, which may cause them discomfort in their lives. Additionally shift of responsibility from government to individuals and making them advocated and responsible for their financial decisions (Brounen, Koedijk, \& Pownall, 2016) this put pressure on individuals to be responsible for financial future and to have saving for future needs. For having sufficient amount of money at the time of need individuals should have proper saving. Saving is gaining much importance at both micro and macro level in human wellbeing and economic development. Khan, Gill, and Hanif (2013); Mansoor and Khattak (2014) have highlighted that saving at macro level save country from foreign capital borrowing which may be a potential loss to economy. Similarly, at individual level, without saving many potential problems can arise in society, such as poverty, high crime rate, divorces among families, mental stress, and individual bankruptcy. Beside this, low saving rates not only raise the long 
term financial issues but also at short term create problems for individuals in meeting expected and unexpected life events (Ahmed \& Mustafa, 2012).

Macrae et al. (2016) mentioned that, many people fail to save funds for retirement despite of increased longevity, reason behind this can be insufficient income, and unavoidable spending which create hindrances in saving even if people wants save. Besides this low saving has been observed in working youth in Pakistan because youth has been found more spending oriented (Subhani, Hassan, \& Osman 2012; Yahya, Zafar, \& Shafiq, 2013; Qureshi, Farooqi, \& Qureshi, 2016; Birari \& Patel, 2014).

Besides overspending, lack of knowledge about money management and budgeting skills are key hindrances in balancing between saving (Garman, Porter \& Mcmillian, 1989). Such issue of lack of knowledge and budgeting skills pertain to financial literacy. Klapper, Lusardi and Oudheusden (2015); Lusardi, and Mitchel (2007) have also highlighted the issue of lack of knowledge (financial literacy) as hindrance in saving decisions. As concern to Pakistan context and target audience, majority of people found as financially illiterate (Bashir et al., 2013 ${ }^{\text {a }}$; Arif, 2015; Bhabha el al., 2014). This highlights the importance of financial literacy as intermediary helping tool for saving decisions.

Furthermore regarding issue pertain to low saving in Pakistan research shows the issue of high dependency ratio due to which individuals face low saving and high spending problem. This has also been noticed in the study of Jamal, Hanif, and Mushtaq (2014) and House Hold Integrated Economic Survey (HIES) in Pakistan during 2015-2016 that many families have high dependency ratio because of lower number of earners, and due to this high dependency major share of their earning is used on monthly expenses of the dependents and other household expenditures. Beside this, increasing rate in expenditure was found higher as compare to increasing rates in income (HIES 2015-2016).

Empirical literature has witnessed several variables affecting saving decisions of working youth. Different variables by different researchers were used to measure saving such as Khan, Gill, and Hanif (2013); Saqib et.al (2016); and Basit, Bashir, and Farooq (2010) used demographic factors to determine the saving in Pakistan. Bashir, Hassan, Nasir, Baber, and Shahid $\left(2013^{b}\right)$ and Mansoor and Khattak (2014) used socio economic and demographic factors to determine saving behavior. Current study has focused to examine the effect of family background and peer role on saving decisions of working youth. Along with this, current study proposed a mediating role of financial literacy among relationship of family background and peer role with saving decisions of working youth.

There for the objectives of this study are,

To investigate the effect of family background and peer role on saving decisions

To determine the relationship of financial literacy with saving decisions

To analyze the effect of family background and peer role on financial literacy

To examine the mediating effect of financial literacy on relationship of family background and peer role with saving decisions.

\section{Literature Review}

\section{Saving}

Growing concerns related to individuals' needs, and to be self-trusted in future balanced saving play important role. People those make rational decisions regarding saving manage their financial resources effectively are more satisfied (Lin et al., 2016). Saving is consider as mean of securing future (Zhang 2009; Zhang, Baumeister, 2006; Modigliani, 1986). Further Katona (1974) defined saving as avoiding from spending entire income. Saving money always 
depends on choices of individuals some save for particular goals (Warneryd, 1999) while some people save for longer terms such as retirement purpose to secure their life after retirement, children education, marriage and some save for short term such as purchase of gadget (Ahmed \& Mustafa, 2012).

Different scholars such as Rha, Montalto, and Hanna, (2006) have highlighted the importance of saving as resource for monetary safety, and reducing future uneasiness (Zaleskiewicz et al., 2013). Further saving has been treated as genetic factor (Cronqvist \& Siegel, 2011). Under this their saving being affected through scarifying gratification as stated by Mischel, Shoda, and Rodriguez (1989); Metcalfe and Mischel (1999) that individual's choice through either to select immediate short term benefits or long term large benefits shows delaying immediate gratification and affect the saving. This also pertain to person's choice between current and or future consumption (Jappelli \& Padula, 2013).

Based on theoretical assumption of life cycle hypothesis, Heckman and Henna (2015) illustrated that, life cycle model anticipate future income as important in saving behavior. Similarly, according to life cycle hypothesis, individual consumption is derived from individuals' long term income and it is being supposed through their position in life cycle (Lee \& Hanna, 2015). Key point under life cycle hypothesis that, individuals smooth out their life time consumption (Ando, \& Modigliani, 1963; Deaton, 2005; Mansoor \& Khattak, 2014), and this can be achieved through proper saving.

\section{Family Background}

Family is one of the important group influencing saving decisions (Kim, Gutter, \& Spangler, 2017). In family parents have greater influence on children's decisions related to finance (Xiao, Tang, Serido, \& Shim, 2011; Bowen, 2002; Shim, Serido, Bosch, \& Tang, 2013). Additional parents are treated as first teachers (Moschis, 1985), which have influence on youth financial decisions (Xiao, Tang, Serido, \& Shim, 2011; Bowen, 2002; Shim, Serido, Bosch, \& Tang, 2013).

\section{Family Background and Saving}

Among family members parents play essential role for encouraging children for saving (Lusardi \& Mitchell 2014). Parents role has been categorized in two ways, some parents do not allow children to be involved in decision, as parents take all decisions, and other category of parents, are interactive in nature, they try to teach their children regarding financial matters (Ribeiro, Fonseca, \& Soares 2018). Similarly, Afsar, Chaudhary, Iqbal, and Aamir (2018) also found that, parents with interactive characteristics also positively associated with saving. Robertson-Rose (2020) also identified dual nature of parents related to financial matters which can have both positive as well as negative effects on savings. Such nature of parents shows varying effects of parents on saving decisions, parents with interactive nature helps to boost saving.

Beside parents siblings also play important role in predicting saving decisions. Among siblings, older sister has positive effects on saving with females, but having negative association with saving while comparing with older brother (Okudaira et al., 2015). While in extended families siblings have negative effect on saving. So keeping in view the literature regarding family background current study has hypothesize the relationship of family background with saving decisions.

H1: Family background significantly affect saving 


\section{Peer Role}

Socially linked group of is referred as peers having many similarities in financial habits, and style of doing jobs and helping the society. There has been seen a multiple significant effects of peers on one's decisions these effects can be positive and or negative (Lieber \& Skimmyhorn, 2018; Constantinides \& Holleschovsky, 2016). Peer effect has been appeared with importance in various fields, such as Lieber and Skimmyhorn, (2018) have identified peer association between life insurance and retirement saving, Gerrans, Moulang, Feng, and Strydom (2018) traced out peer effect on investment strategies, and risk taking in decision making by entrepreneurs (Lopera \& Marchand, 2018).

\section{Peer Role and Saving}

Peers can affect the saving in both ways in positive and or in negative way. As Kast, Meier and Pomeranz, (2016) identified in experimental study that, peers have increased the saving habits of their peer members. While Jamal, Ramlan, Karim, and Osman (2015) have identified negative effect of peers on saving abilities, because at work place while selecting any financial product for savings normally people follow their peers but not the returns of that financial product (Mugerman, Sade \& Shayo, 2014).

Based on scholarly evidences, peer role seems to be influencing saving decisions in both directions positively and or negatively.

H2: Peer role significantly affects saving

\section{Financial Literacy}

Individuals' set of capabilities used for making decisions about money management is known as financial literacy (Trombitas, 2011; Fernandes, lynch, \& Netemeyer, 2014; Lusardi \& Mitchell, 2011 a, b; Hilgert, Hogarth, \& Beverly 2003; Ahmed \& Mustafa, 2012; Mandell, 2008). Financial literacy can also be treated as numeracy skills needed for financial decision making. Further financial literacy as set of individuals' abilities through which economic information can be used to make sound decisions about pension planning, wealth, and debt management (Lusardi \& Mitchel 2014). According to (Lusardi \& Mitchell, 2011 ${ }^{\text {b) }}$ financial literacy also helps in interest rate calculation. With good level of financial literacy people can make good financial decisions like retirement planning (saving) (Lusardi \& Mitchell, 2006, 2008 ${ }^{\text {a b }}$; Lusardi \& Mitchell, 2011 ${ }^{\text {b }}$ Potrich, Viera, \& Kirch, 2018).

OECD (2005) highlighted importance of financial literacy work working youth and there is lack of financial literacy in developed world such as Japan, UK, Australia and USA. Similarly lack of financial literacy was not only found in USA but was also in rest of the world (Ambuehl, Bernheim, \& Lusardi 2017; Huston, 2012). Similarly, in local context of Pakistan literature has evident the lack of financial literacy (Bashir et al., 2013a; Arif 2015; Bhabha el al., 2014).

\section{Family Background and Financial Literacy}

Family play key role in financial literacy development in family individuals (Amari, Salhi, \& Jarboui, 2020). Mancebon, Mediavilla and Sancho (2019) found significant role of family in financial literacy development. Findings show that family is treated as first agent in reading, and math scores are key factors in enhancement of financial skills. Beside this, parents play important role to their children and give them right conditions (Peng, Bartholomae, Fox, \& Cravener, 2007). Beside this parents develop financial knowledge or literacy of their children better than they learnt at schools (Shim et al., 2010). Hence this shows importance of literacy also as it helped in making sound financial decisions especially saving, as family background 
has impact on financial literacy (Longobardi, Pagliuca, \& Regoli, 2017). In local context of Pakistan which has versatile culture and family structures. So current study has attempted to investigate the role of family background to wards financial literacy and proposed as:

H3: Family background significantly affect financial literacy

\section{Peer Role and Financial Literacy}

Literature shows that individuals get financial knowledge or literacy not only from the family, but also gain from other social agents (Hilgert, Hogarth, \& Beverly, 2003; Moore \& Bowman, 2006; Kretschmer \& Pike, 2010; Masche, 2010). Likewise peer role has positive effect on financial literacy (Bowen, 2002; Mitchel, Lusardi, Curto, 2009; Isomidinova \& Singh, 2017) and peers are also cost effective source of gaining knowledge instead of hiring consultant (Chang, 2005). As time passes like increasing age peer effect increase (Churchill \& Moschis, 1979) because in early ages family effect is on higher side, but when individuals' age increase its social circle also increases such as peer communication. Hence peer effect in working life can more on one's decisions as peer spend more time with other peers as compare to family. Based on the study by Lusardi, Mitchel, and Curto (2010) that peers have substantial influence on financial literacy of other peers in long run as compare to the effect of peer in current relationship time. Similarly, Mitchel, Lusardi, and Curto, (2009) also found substantial effect of peers on financial literacy. Hence based on cited evidences current study has proposed the relationship of peers on financial literacy.

H4: Peer role significantly affects financial literacy

\section{Financial Literacy and Saving}

Financial literacy has remained under debate since long, and is treated as one of the important predictor in research especially for working youth (OECD (2005). Additionaly, financial literacy is also a good predictor retirement saving (Lusardi \& Mitchell, 2011 ; Potrich, Viera, \& Kirch, 2018). However, due to low level of financial literacy people do not plan for retirement planning properly (Lusardi \& Mitchel, 2011c). Beside this, financial literacy also helpful for saving by customers also, such as Afrian, and Asandimitra (2020) have highlighted that financial literacy predict saving by $72.1 \%$ further adding more higher level of financial literature helps in managing finance and saving by customers in Indonesia.

While in local context of Pakistan, Arif (2015); Bhabha el al. (2014); Bashir et.al. (2013 highlighted the work and importance of financial literacy and found majority of the people in Pakistan lacking behind in financial literacy. Even though financial literacy is important for making sound financial decisions (Grohmann, Kouwenberg, \& Menkhoff, 2015). In spite of that people due to lack of financial literacy these people are weak in good financial choices and it is harmful for both individuals and comunity itself (Hussain \& Sajjad, 2016). Local context literature evident that people with financial education, knowledge or literacy are good at making good decisions regarding retirement saving as compare to those who are weak in financial literacy. Therefor based on the cited scholarly work, current study has proposed that:

H5: Financial literacy will significantly affect saving

\section{Financial Literacy as Mediator}

Based on the literature regarding mediating role of financial literacy, Ameliawati, and Setiyani (2018) found mediated results of financial literacy among financial socialization, financial attitude, and financial experience with financial management behavior. Along with this, 
financial literacy has also mediated the relationship of financial education with financial satisfaction (Xiao \& Porto, 2017). Furthermore financial literacy has performed mediating role between various variables, such as investment know how, basic money management, attitude to money, financial planning, and financial activities with financial satisfaction (Ali, Rahman, \& Bakkar, 2013). Social influencing predict saving behavior (Mpaata, Koskei, \& Saina, 2020).

Concerning to the current study framework, current study has attempted to know the effect of family background, and peer role on saving decisions, peer role and family background are treated as social factors that affects saving decisions. With regard to family background there is categorical and dual nature of parents (positive and negative) (Ribeiro, Fonseca, \& Soares 2018; Robertson-Rose 2020). Due to this categorical nature from family, has different effect on saving. While under peer role have both positive and also negative effects on saving (Lieber \& Skimmyhorn, 2018; Constantinides \& Holleschovsky, 2016). In spite of positive parental and peer support, working youth found less saving (Crossley, Emmerson, \& Leicester 2012), similarly, in Pakistan working youth found with less saving (Qureshi, Farooqi, \& Qureshi, 2016; Birari \& Patel, 2014; Yahya, Zafar, \& Shafiq, 2013; Subhani, Hassan, \& Osman, 2012).

From cited evidence this can be assumed that in spite of support from parents and peers working youth is less saving orient, means there is missing some important element which has greater effect on saving decision. So current study traced out that working youth are also found less financially literate (Arif, 2015; Bhabha el al., 2014; Bashir et al., 2013 ${ }^{\text {a }}$. Based on the gap of lack of financial literacy, current study has proposed financial literacy as mediator among association of family background, peer role with saving decisions, and hypothesized the relationship as:

H6: Financial literacy will mediate the relationship of family background with saving

H7: Financial literacy will mediate the relationship of peer role with saving

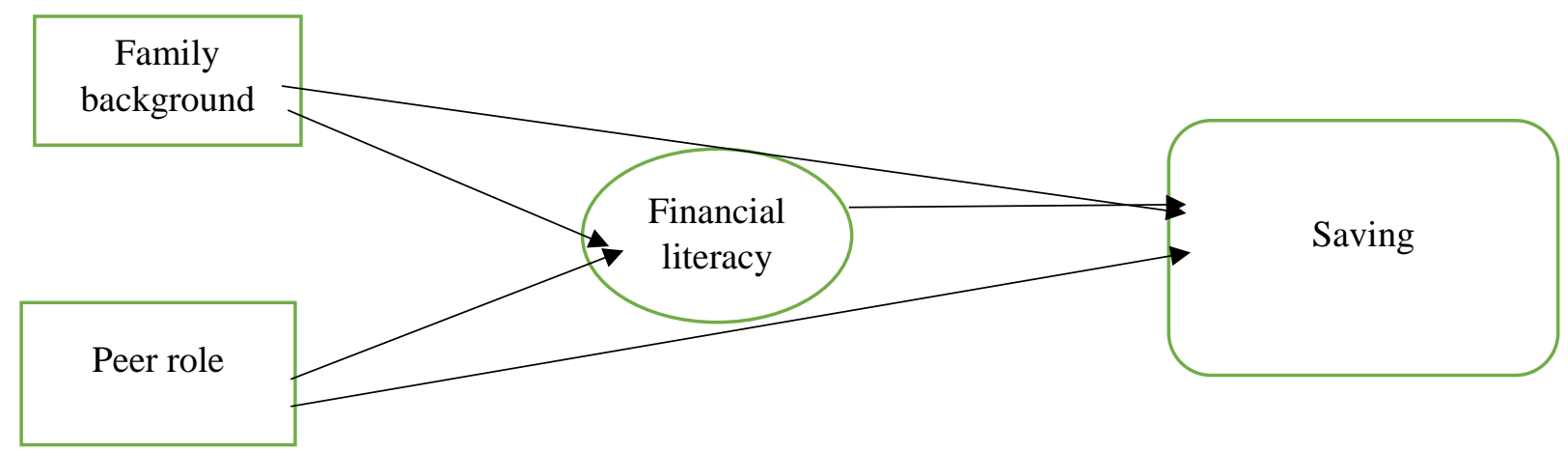

Figure 01: Framework

\section{Methodology}

This section talks about methodology applied in current research.

\section{Instrument}

Questionnaire was adapted as research instrument for current study. In current study dependent variable was measured through 13 items adapted from updated version in 2015 of instrument developed in 2009 Financial Capability Survey (2009; 2012; 2015); Potrich, Vieira, and Kirch (2015); Jorgensen and Savla (2010). For measuring independent variables, peer role was measured with 5 items adapted from the instrument designed by Jorgensen and Savla (2010), original instrument was used in Hancock, Jorgensen, and Swanson (2013); 
Jorgensen et. al. (2016). beside this one item was adapted from Clarke et.al. (2005). For measuring effect of family back grounding current study 8 items were adapted from both survey instruments; Financial Capability Survey (2015); and Jorgensen and Savla (2010). Instrument as Financial Capability Survey (2015); was updated version of the instrument originally designed by Lusardi in 2009 as Financial Capability Survey (2009). This instrument has widely been used in various scholarly works such as Ambuehl, Bernheim, and Lusardi (2017; 2016); Mitchel and Lusardi (2015); Clark, Lusardi, and Mitchel (2017; 2014); Boisclair, Lusardi, and Michaud (2014); Heinberg et.al. (2014); Lusardi and Scheresberg (2013). Finally for measuring the effect of financial literacy directly on saving decisions, and as mediator between relationship of peer role, family background with saving decisions, current study adapted well known 7 items ( 3 questions for basic financial literacy, four questions for advanced financial literacy) were adapted from scholarly work by Lusardi and Mitchel (2008; 2009; 2014) for measuring basic financial literacy, and 4 questions out of 7 questions were adapted from Lusardi and Mitchel (2009) and Hasting et.al. (2013); van Rooij, Lusardi, Alessie, and Rob (2012) for measuring advanced financial literacy.

\section{Data Collection}

Data for this study were collected in year 2019 from youth between age of 19 years to 35 years, working in different organizations at various locations in Pakistan through survey instrument covering the questions about current study research framework. Total 576 questionnaires were distributed among the target audiences which were selected through stratified random sampling. For easiness in data collection, head of particular organization at given location were contacted for having list of employees for easy approaching these working youth.

\section{Response Rate and Data Screening}

Out of 576 questionnaires 368 instruments were collected back which represent $63.89 \%$, after sorting out instruments, 49 instruments were found unusable because of half-filled and straight-line filled, after that 319 instruments were found as usable. After this data screening process was applied through SPSS23 during data screening 10 instruments were removed as outliers. So final analyses of measurement model and structural model was done by applying structural equation modeling through Smart PLS3. 


\section{Demographic Statistics of Respondents}

\section{Table 1}

Demographic Characteristics of the Participants ( $n=309)$

\begin{tabular}{|c|c|c|}
\hline Characteristics & Frequency & Percentage \\
\hline \multicolumn{3}{|l|}{ Gender } \\
\hline Male & 264 & $85.4 \%$ \\
\hline Female & 45 & $14.6 \%$ \\
\hline \multicolumn{3}{|l|}{ Age } \\
\hline $21-25$ years & 48 & $15.5 \%$ \\
\hline $26-30$ years & 164 & $53.1 \%$ \\
\hline $31-35$ years & 97 & $31.4 \%$ \\
\hline \multicolumn{3}{|l|}{ Education } \\
\hline High School & 02 & $0.6 \%$ \\
\hline College Diploma & 05 & $1.6 \%$ \\
\hline Bachelor degree & 112 & $36.2 \%$ \\
\hline Post graduate degree & 190 & $61.5 \%$ \\
\hline \multicolumn{3}{|l|}{ Marital status } \\
\hline Single & 200 & $64.7 \%$ \\
\hline Married & 109 & $35.3 \%$ \\
\hline \multicolumn{3}{|l|}{ Family members } \\
\hline 2 & 18 & $5.8 \%$ \\
\hline 3 & 07 & $2.3 \%$ \\
\hline 4 & 40 & $12.9 \%$ \\
\hline 5 & 00 & $0 \%$ \\
\hline More than five & 244 & $79 \%$ \\
\hline \multicolumn{3}{|l|}{ Work Status } \\
\hline Full time employees & 264 & $85.4 \%$ \\
\hline Part time employees & 45 & $14.6 \%$ \\
\hline \multicolumn{3}{|l|}{ Spouse/Partner work status } \\
\hline Self-employed & 53 & $17.2 \%$ \\
\hline Full time employee & 77 & $24.9 \%$ \\
\hline Part time employee & 34 & $11 \%$ \\
\hline Others & 145 & $46.9 \%$ \\
\hline \multicolumn{3}{|l|}{ Income Level } \\
\hline Less Than Rs. 15000 & 10 & $3.2 \%$ \\
\hline Rs. 16,000 to Rs 25,000 & 26 & $8.4 \%$ \\
\hline Rs. 26,000 to Rs 35,000 & 30 & $9.7 \%$ \\
\hline Rs. 36,000 to Rs. 50,000 & 162 & $52.4 \%$ \\
\hline
\end{tabular}

\section{Data Analyses and Findings}

Hypothesized relationships were tested through structural equation model. Current research used two key approaches recommended by Anderson and Gerbing (1988). In first step current study applied assessment of measurement model through PLS algorithm where reliability and validity of construct was assessed. After ensuring about adequate reliability and validity, current study moved to second step of assessment of structural model through bootstrapping for testing hypothesized relationships. In measurement model assessment construct reliability, validity was assessed through criteria recommended by Fornell and Larcker (1981). For measuring reliability of the constructs in current study CR and AVE value, alpha values were used which shows reliability at lower level, but beside CR, AVE and alpha values rho_A criteria can be used for reliability measurement (Joukes et al., 2018). Rho (Dillon-Goldstein's rho or Jöreskog) value can be a good predictor of reliability (DeBruyn et al., 2017). Recommended range of rho value is 0.70 or above (Chin, 1998). Rho values were found well above the criteria except for saving (0.564). Rho can be said as suitable substitute for $C R$, 
alpha and AVE. based on rho values current study show adequate level of reliability of the construct.

Further for measuring discriminant validity, current study adapted fornell and larcker (1981) criteria of squire root of AVE. Value of squire root of AVE are appended in table 3. Regarding squire root of AVE, all values were found greater than correlation values, and this shows adequate level of discriminant validity of the constructs. Further to this for further to this, for discriminant validity HTMT values were also considered. According to Henseler, Ringle, and Sarstedt (2015) is a criteria can be used for discriminant validity, it is recommended that HTMT value must be less than $\mathrm{HTMT}_{0.85}$ (Clark \& Watson 1985; Kline, 2011) or HTMT 0.90 (Gold, Malhotra \& Segars 2001; Teo, Srivastava, \& Jiang, 2008). Values of HTMT factor, were found less than HTMT $_{0.85}$ in current study and results about HTMT values are appended in table 3. Hence by following HTMT values it shows the adequate level of discriminant validity.

Table 2

Construct reliability and validity,

\begin{tabular}{lllll}
\hline Construct & rho_A & CR & alpha & AVE \\
\hline FB & & & & \\
& 0.804 & 0.597 & 0.593 & 0.284 \\
FL & & & & \\
PR & 0.817 & 0.642 & 0.531 & 0.392 \\
SV & 0.780 & 0.761 & 0.616 & 0.436 \\
\hline
\end{tabular}

Table 3

Squire root of AVE and HTMT values

\begin{tabular}{|c|c|c|c|c|c|c|c|c|}
\hline \multirow[t]{2}{*}{ Construct } & \multicolumn{4}{|c|}{ Sq: root AVE } & \multicolumn{3}{|c|}{ HTMT } & \multirow[b]{2}{*}{ SV } \\
\hline & FB & FL & PR & SV & FB & $\mathbf{F L}$ & PR & \\
\hline FB & 0.533 & -- & & & -- & & & \\
\hline $\mathrm{FL}$ & -0.534 & 0.626 & -- & & 0.666 & -- & & \\
\hline PR & 0.393 & -0.539 & 0.661 & -- & 0.557 & 0.720 & -- & \\
\hline SV & -0.423 & 0.551 & -0.452 & 0.349 & 0.466 & 0.582 & 0.519 & -- \\
\hline
\end{tabular}




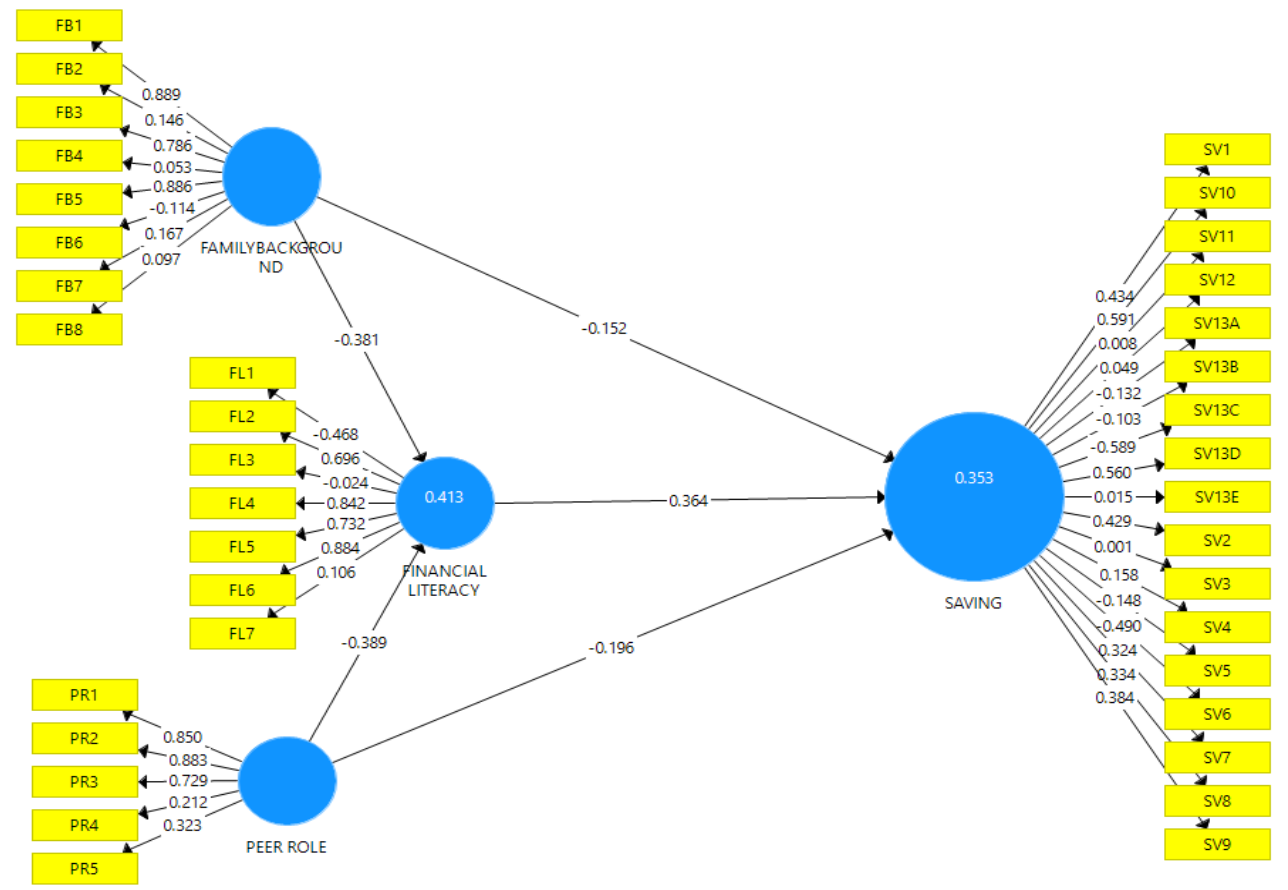

Figure 2 measurement model

Table 4

$R^{2}$ and $f^{2}$

\begin{tabular}{|c|c|c|c|c|c|}
\hline & \multirow[t]{2}{*}{$\mathbf{R}^{2}$} & \multirow[t]{2}{*}{ adjstd $R^{2}$} & \multicolumn{2}{|c|}{$f^{2}$} & \multirow[t]{2}{*}{ level of $\mathbf{f}^{2}$} \\
\hline & & & $\mathbf{F L}$ & SV & \\
\hline FB & & & 0.209 & 0.025 & moderated on FB on FL, weak on SV \\
\hline $\mathrm{FL}$ & 0.413 & 0.409 & & 0.121 & weak effect of FL on SV \\
\hline PR & & & 0.218 & 0.041 & moderated on PR on FL, weak on SV \\
\hline SV & 0.353 & 0.347 & & & \\
\hline
\end{tabular}

Based on the $\mathrm{R}^{2}$ values current study shows adequate variation in mediating or dependent variable through one or more independent variables (Hair et al., 2006; Elliot \& wood 2007). In current study family background, peer role are independent variable, and financial literacy is as mediating variable, and saving is dependent variable.

Beside this, effect size of each independent variable was also checked through $\mathrm{f}^{2}$ values (Chin 1998). While examining $f^{2}$ values, in current research shows moderated effect of family background and peer role on financial literacy (mediating variable), and weak effect on saving (dependent variable). Beside this there is also weak effect of financial literacy on saving.

On findings about data fulfilling the criteria of normality, linearity and multicolinearity, hypothesis were tested through assessment of structural model by applying bootstrapping through Smart PLS3. Results of model assessed through structural equation modeling is depicted in figure 3 


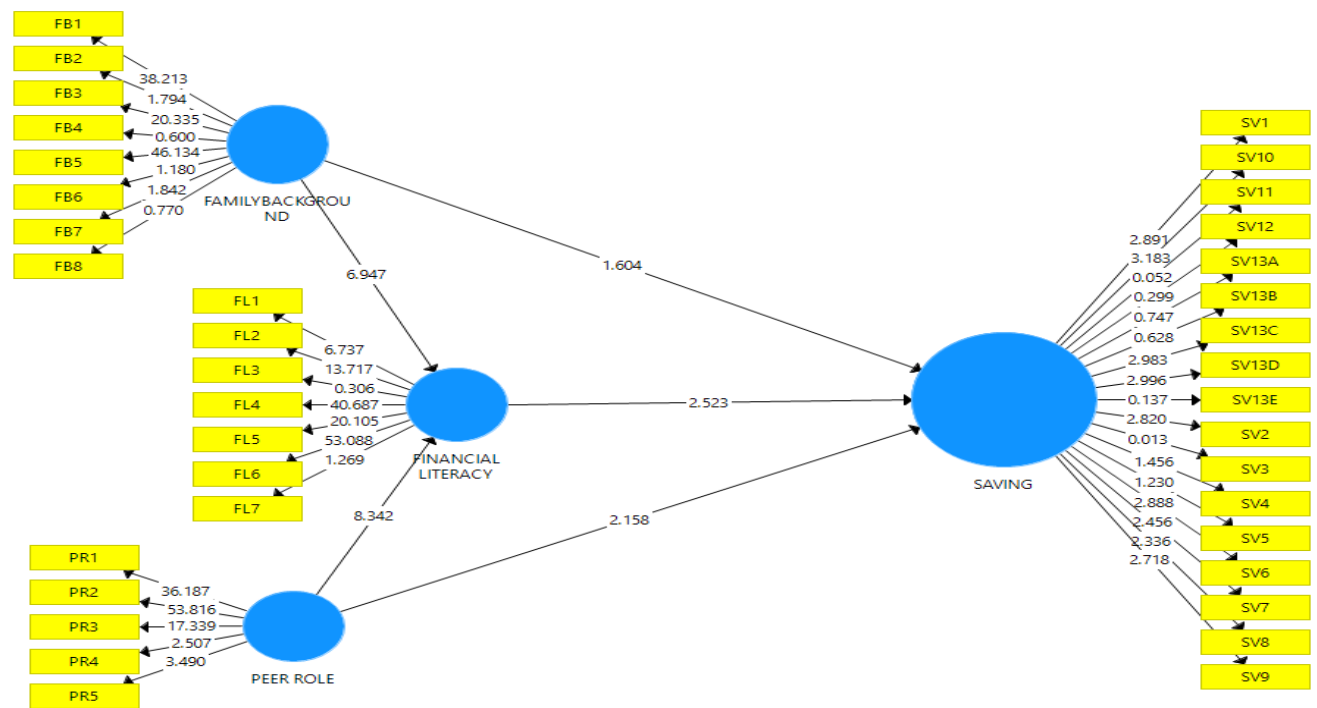

Figure 3; Structural model

Table 5

Structural Path Model

\begin{tabular}{llllll}
\hline Model & beta & Std: & t value & p value, & results \\
\hline$H 1: F B \rightarrow S V$ & -0.152 & 0.095 & 1.604 & 0.109 & rejected \\
$H 2 ; P R \rightarrow S V$ & -0.196 & 0.091 & 2.158 & 0.031 & accepted \\
$H 3: F B \rightarrow F L$ & -0.381 & 0.055 & 6.947 & 0.000 & accepted \\
$H 4: P R \rightarrow F L$ & -0.389 & 0.047 & 8.342 & 0.000 & accepted \\
$H 5: F L \rightarrow S V$ & 0.364 & 0.144 & 2.523 & 0.012 & accepted \\
$H 6: F B \rightarrow F L \rightarrow S V$ & -0.139 & 0.062 & 2.223 & 0.026 & accepted \\
$H 7: P R \rightarrow F L \rightarrow S V$ & -0.142 & 0.060 & 2.361 & 0.018 & accepted \\
\hline
\end{tabular}

Results regarding hypothesis depicted in in table 5 . Finding about hypothesis $H 1$ (FB $\rightarrow S V$ ) shows the negative in significant effect of family background on saving decisions $(\beta=-0.152, t$ $=1.604, p<=0.109$ ) hence $\mathrm{H} 1$ was rejected in current study based on $\mathrm{p}$ value. While observing the effect of peer role in hypothesis $\mathrm{H} 2(\mathrm{PR} \rightarrow \mathrm{SV})$ shows negative but significant effect of peer role on saving decisions $(\beta=-0.196, t=2.158, p<=0.031)$ based on the results current study showed that $\mathrm{H} 2$ was accepted. Beside this, while examining effect of family background and peer role on financial literacy in $\mathrm{H} 3(\mathrm{FB} \rightarrow \mathrm{FL}, \beta=-0.381, t=6.947, p<=0.000)$ and $\mathrm{H} 4(\mathrm{PR} \rightarrow \mathrm{FL}$, $\beta=-0.389$, $t$ value $=8.342, p<=0.000$ ) was also found negative significant and both $\mathrm{H} 3$ and $\mathrm{H} 4$ hypothesis were accepted. Current study also examined the effect of financial literacy on saving decisions in $\mathrm{H} 5$ ( $F L \rightarrow S V, \beta=0.364, t=2.523, p<=0.012$ ) current study found positive significant effect of financial literacy on saving decisions, based on the results $\mathrm{H} 5$ has been accepted. Beside the direct relationships, current study also tested indirect relationships, of family background and peer role with saving decisions through mediating effect of financial literacy. While examining mediating effect in $\mathrm{H} 6(\mathrm{FB} \rightarrow \mathrm{FL} \rightarrow \mathrm{SV}, \beta=-0.139, \mathrm{t}=2.223, \mathrm{p}<=0.026)$ and in $\mathrm{H} 7(\beta=-0.142, \mathrm{t}=2.361 \mathrm{p}<=0.018)$.

Based on the results of mediating effect significant. In $\mathrm{H} 6(\mathrm{FB} \rightarrow \mathrm{FL} \rightarrow \mathrm{SV})$ current study found negative but significant effect, while observing the direct effect of family background on saving decisions in $\mathrm{H} 1$ (FB $\rightarrow \mathrm{SV}$ ) was insignificant relationship, but in mediation through financial literacy this insignificant relationship changed to significant results, so in current study, financial literacy has mediated the effect of family background on saving decisions and $\mathrm{H} 6$ has been accepted. Similarly, in $\mathrm{H7}$ current study also found the negative but significant 
effects, while comparing results of mediating relationship with direct relationship, $t$ values during direct relationship ( $\mathrm{H} 2)$ was 2.158 and t value in mediating effect was raised to 2.361 in $(\mathrm{H} 7)$, and $p$ value of direct relationship was 0.031 in $(\mathrm{H} 2)$ and $p$ value in mediating effect (H7) was decreased to 0.018 in $\mathrm{H7}$, these comparative results shows that financial literacy has mediated the effect of peer role on saving decisions.

\section{Discussions}

Current study was aimed to investigate the effect of family background on saving decision in $\mathrm{H} 1$. In $\mathrm{H} 1$ current study has proposed the significant effect of family background on saving decisions, while testing the hypothesis, current study found negative insignificant effects of family background on saving decisions. One of the main reason of insignificant results in current study about relationship of family background with saving decision could be the dual or categorical relationship of family members (parents) highlighted in literature. As stated by Ribeiro, Fonseca, and Soares (2018) that in one category parents want to teach their children about financial tasks and guide them in making financial decisions, which can be beneficial for children to make saving decisions rationally, while in category two, parents do not guide or teach their children about financial matters, which may adversely affect the children, so children may not become rational in making good financial decisions especially about saving. Beside parents, among family sibling effect can also be important factor which could lead to insignificant effect as Okudaira et.al. (2015) stated the gender difference as older sister has positive association with sister and negative association with older brother. So from such analyses it can be concluded family background can have insignificant effect on saving decisions.

While investigating effect of peer role on saving decisions current study hypothesized in $\mathrm{H} 2$ that, peer role will significantly affect the saving decisions. While testing the relationship, current study also found significant results but negative beta. While justifying the negative beta concerning to effect of peer role on saving decision also be possible effect (Jamal et al., 2015).

Beside this current study also tested the effect of family background and peer role on financial literacy. In $\mathrm{H} 3$ ( $\mathrm{FB} \rightarrow \mathrm{FL}$ ), current found negative significant influence of family background on financial literacy, negative beta findings of family are also in line with support from literature (Sohn, Joo, Grable, Lee and Kim (2012). Further in line with this, peer role effect on financial literacy was also assessed in $\mathrm{H} 4(\mathrm{PR} \rightarrow \mathrm{FL})$ current study found significant results with negative beta. Results of current study are in line with the literature as Lusardi, Mitchel and Curto (2010) stated that peers negatively affect financial literacy in current situation as compared to long term effect. Further to this, negative beta results in current study also supported by Sohn et.al. (2012).

Current study also assessed the effect of financial literacy on saving decision under hypothesis $\mathrm{H} 5$ ( $\mathrm{FL} \rightarrow \mathrm{SV}$ ) current study found positive significant effect of financial literacy on saving decisions. As financial literacy is the key helping tool in all stages of life for making informed decisions (Lusardi, 2008 ${ }^{\text {b }}$; Mandell, 2008; Lusardi \& Mitchel, 2014). Current study findings are also supported by the literature (Lusardi \& Mitchell, 2006, 2008; Lusardi \& Mitchell, $2011^{\text {b}}$ ). Study by Mahdzan and Tabiani (2013); Delafrooz and Paim (2011) shows the positive and significant effect of financial literacy on saving decisions.

Beside direct relationships, current study also tested the mediating effect of financial literacy on relationship of family background and peer role with saving in $\mathrm{H} 6$ and $\mathrm{H} 7$. Current study found significant mediating effect of financial literacy on relationship of family background 
and peer role with saving decisions. Because financial literacy is only the way which helps in making informed (Lusardi, 2008 ${ }^{\text {b }}$; Mandell, 2008; Lusardi \& Mitchel, 2014) decisions.

\section{Implications}

Theoretically, current study findings are under the umbrella of relative income hypothesis (Duesenberry, 1948) which states that, individuals decisions especially regarding saving are not only depends on own saving habits but are also affected by social class (peers and family). Another theoretical implication of current study is linked with life cycle hypothesis (Ando \& Modigliani 1963) that people try to bring consistency in life time resources such as financial literacy which involve self-control and mental accounting essential for making good financial decisions.

While talking about practical implications current study findings suggest that, despite of key role played by family, and peers in financial decisions, individuals own financial literacy has greater worth in making financial decisions. Financial institutions can encourage working youth for better saving decisions by offering lucrative saving deposit rates.

\section{Conclusions}

In current study peer role and financial literacy are the factors affecting saving decisions significantly during direct relationship. Only family background shown insignificant effect on saving decisions. Beside this, peer role and family background have shown significant relationship with financial literacy. While testing direct effect of family background on saving decisions. Mainly in mediating relationship all predicting variables (family background, peer role as independent variables and financial literacy as mediating variable) shown significant results with dependent variable (saving decision).

Based on the significant results of financial literacy as mediator it can be concluded that financial literacy has been proved as a good mediator between relationship of family background and peer role with saving decision. Further the current study results shows that financial literacy is an essential factor which is needed for rational financial decisions. So therefore policy makers and government authorities for implementing policies should focus on enhancing financial literacy of individuals for onward enabling them to make best possible financial decisions to secure their financial future.

\section{References}

Afriani, T., \& Asandimitra, N. (2020). Determinants of Customer Preference to Save in Islamic Bank. al-Uqud: Journal of Islamic Economics, 4(1), 1-17.

Afsar, J., Chaudhary, G. M., Iqbal, Z., \& Aamir, M. (2018). Impact of Financial Literacy and Parental Socialization on the Saving Behavior of University Level Students. Journal of Accounting and Finance in Emerging Economies, 4(2), 133-140.

Ahmed, S., \& Mustafa, F. (2012) Nationwide Financial Literacy Program. A Survey Initiated by State Bank of Pakistan (SBP).

Ali, A., Rahman, M. S. A., \& Bakar, A. (2013). Financial literacy and satisfaction in Malaysia: A pilot study. International Journal of Trade, Economics and Finance, 4 (5), 319-324. doi:10.7763/IJTEF.2013.V4.309

Amari, M., Salhi, B., \& Jarboui, A. (2020). Evaluating the effects of sociodemographic characteristics and financial education on saving behavior. International Journal of Sociology and Social Policy.

Ambuehl, S., Bernheim, B. D., \& Lusardi, A. (2016). GFLEC Working Paper Series. 
Ambuehl, S., Bernheim, B. D., \& Lusardi, A. (2017). A Method for Evaluating the Quality of Financial Decision Making, with an Application to Financial Education. Global Financial Literacy Excellence Center Working Papers Series: (WP 2017-2). Retrieved from. http://gflec.org/research/.

Ambuehl, S., Bernheim, B. D., \& Lusardi, A. (2017). A Method for Evaluating the Quality of Financial Decision Making, with an Application to Financial Education. Global Financial Literacy Excellence Center Working Papers Series: (WP 2017-2). Retrieved from. http://gflec.org/research/.

Ameliawati, M., \& Setiyani, R. (2018). The influence of financial attitude, financial socialization, and financial experience to financial management behavior with financial literacy as the mediation variable. KnE Social Sciences, 811-832.

Anderson, J. C., \& Gerbing, D. W. (1988). Structural equation modeling in practice: A review and recommended two-step approach. Psychological bulletin, 103(3), 411.

Ando, A., \& Modigliani, F. (1963). The life cycle hypothesis of saving: Aggregate implications and tests. The American Economic Review, 53(1), 55-84.

Ando, A., \& Modigliani, F. (1963). The" life cycle" hypothesis of saving: Aggregate implications and tests. The American economic review, 53(1), 55-84.

Arif, K. (2015). Financial Literacy and other Factors Influencing Individuals' Investment Decision: Evidence from a Developing Economy (Pakistan) Journal of Poverty, Investment and Development an International Peer-reviewed Journal. Journal of Poverty, Investment and Development, iiste, 12.74-84

Bashir, T., Arshad, A., Nazir, A., \& Afzal, N. (2013 ${ }^{\mathrm{a}}$. Financial literacy and influence of psychosocial factors. European Scientific Journal, ESJ, 9(28). 384-404

Bashir, T., Hassan, A., Nasir, S., Baber, A., \& Shahid, W. (2013 $\left.{ }^{b}\right)$. Gender difference in savings behavior and its determinants: Patron from Pakistan. Journal of Business and Management, 9(6), 74-86

Basit, A. B., Bashir, F., \& Farooq, F. (2010). How do savings differ among various earner groups in Pakistan? Empirical evidence from Multan district. Pakistan Journal of Social Sciences (PJSS), 30(2), 219-233

Bhabha, J. I., Khan, S., Qureshi, Q. A., Naeem, A., \& Khan, I. (2014). Impact of financial literacy on saving-investment behavior of working women in the developing countries. Research Journal of Finance and Accounting,5(13), 118-122.

Birari, A., \& Patil, U. (2014). Spending \& saving habits of youth in the city of Aurangabad. The SIJ Transactions on Industrial, Financial \& Business Management (IFBM),2(3), 158-165.

Boisclair, D., Lusardi, A., \& Michaud, P. C. (2014). Financial literacy and retirement planning in Canada. Journal of Pension Economics \& Finance, 16(3), 277-296.

Bowen, C. F. (2002). Financial knowledge of teens and their parents. Financial counseling and planning, 13(2), 93-102.

Bowen, C. F. (2002). Financial knowledge of teens and their parents. Financial counseling and planning, 13(2), 93-102.

Brounen, D., Koedijk, K. G., \& Pownall, R. A. J. (2016). Household financial planning and savings behavior. Journal of International Money and Finance, 69, 95-107.

Chang, M. L. (2005). With a little help from my friends (and my financial planner). Social Forces, 83(4), 1469-1497.

Chin, W. W. (1998). The partial least squares approach to structural equation modeling. Modern Methods for Business Research, 295(2), 295-336. 
Churchill, J. G. A., \& Moschis, G. P. (1979). Television and interpersonal influences on adolescent consumer learning. Journal of consumer research, 6(1), 23-35.

Clark, L. A., \& Watson, D. (1995). Constructing validity: basic issues in objective scale development. Psychological Assessment, 7(3), 309-319.

Clark, R. L., Lusardi, A., \& Mitchell, O. S. (2014). Financial knowledge and 401 (k) investment performance. Global Financial Literacy Excellence Center Working Paper Series (No. w2014-1). Retried from. http://gflec.org/research/.

Clark, R., Lusardi, A., \& Mitchell, O. S. (2017). Financial knowledge and 401 (k) investment performance: a case study. Journal of Pension Economics \& Finance, 16(3), 324-347.

Clarke, M. C., Heaton, M. B., Israelsen, C. L., \& Eggett, D. L. (2005). The acquisition of family financial roles and responsibilities. Family and Consumer Sciences Research Journal, 33(4), 321-340.

Constantinides, E., \& Holleschovsky, N. I. (2016). Impact of online product reviews on purchasing decisions. In $12^{\text {th }}$ International Conference on Web Information Systems and Technologies 1, 271-278

Cronqvist, H., \& Siegel, S. (2015). The origins of savings behavior. Journal of Political Economy, 123(1), 123-169.

Crossley, T. F., Emmerson, C., \& Leicester, A. (2012). Raising household saving. Institute For Fiscal Studies, London February.

Deaton, A. (2005). 'Franco Modigliani and the life-cycle theory of consumption, Banca Nazionale del Lavo Quarterly Review, 58, 91-107

DeBruyn, S., Wouters, E., Ponnet, K., Van Damme, J., Van Hal, G. (2017). Task Force substance use in Flemish universities and colleges. The psychometric properties of a shortened Dutch version of the consequences scale used in the Core alcohol and drug survey. PloS one, 12(12), e0187876.

Delafrooz, N., \& Paim, L. H. (2011). Determinants of saving behavior and financial problem among employees in Malaysia. Australian Journal of Basic and Applied Sciences, 5(7), 222-228.

Duesenberry, J. S. (1948). Income-consumption relations and their implications. Lloyd Metzler Income, Employment and Public Policy, New York: WW Norton \& Company, Inc.

Elliott, A. C., \& Woodward, W. A. (2007). Statistical analysis quick reference guidebook: With SPSS examples: Thousand Oaks, CA: Sage.

Fernandes, D., Lynch Jr, J. G., \& Netemeyer, R. G. (2014). Financial literacy, financial education, and downstream financial behaviors. Management Science, 60(8), 1861-1883.

Financial capability survey. (2009) National Financial Capability Study State-by-State Survey Instrument Prepared for the Finra Investor Education Foundation by Applied Research \& Consulting Llc

Financial capability survey. (2012) National Financial Capability Study State-by-State Survey Instrument Prepared for the Finra Investor Education Foundation by Applied Research \& Consulting Llc

Financial capability survey. (2015) National Financial Capability Study State-by-State Survey Instrument Prepared for the Finra Investor Education Foundation by Applied Research \& Consulting Llc

Fornell, C. G., \& Larcker, D. F. (1981). Evaluating structural equation models with unobservable variables and measurement error. Journal of Marketing Research, 18(1), 39-50. 
Garman, E., Porter, N., \& McMillion, J. (1989). Financial counseling by a corporation with a large number of employees. Proceedings of the 18th Annual Southeaster Regional Family

Economics/Home Management Conference, pp. 76-84.

Gerrans, P., Moulang, C., Feng, J., \& Strydom, M. (2018). Individual and peer effects in retirement savings investment choices. Pacific-Basin Finance Journal, 47, 150-165.

Gold, A. H., Malhotra, A., \& Segars, A. H. (2001). Knowledge management: an organizational capabilities perspective. Journal of Management Information Systems, 18(1), 185-214.

Grohmann, A., Kouwenberg, R., \& Menkhoff, L. (2015). Childhood roots of financial literacy. Journal of Economic Psychology, 51, 114-133.

Hair, J. F., Black, W. C., Babin, B. J., Anderson, R. E., \& Tatham, R. L. (2006).Multivariate data analysis. Upper Saddle River, NJ: Pearson Prentice Hall.

Hancock, A. M., Jorgensen, B. L., \& Swanson, M. S. (2013). College students and credit card use: The role of parents, work experience, financial knowledge, and credit card attitudes. Journal of Family and Economic Issues, 34(4), 369-381.

Hastings, J. S., Madrian, B. C., \& Skimmyhorn, W. L. (2013). Financial literacy, financial education, and economic outcomes. Annual Review of Economics, 5(1), 347-373

Heckman, S. J., and Hanna, S. D. (2015), "Individual and institutional factors related to lowincome household saving behavior", Journal of Financial Counseling and Planning, 26(2)187-199.

Heinberg, A., Hung, A., Kapteyn, A., Lusardi, A., Samek, A. S., \& Yoong, J. (2014). Five steps to planning success: experimental evidence from US households. Published in Oxford Review of Economic Policy, 30(4), 697-724.

Henseler, J., Ringle, C. M., \& Sarstedt, M. (2015). A new criterion for assessing discriminant validity in variance-based structural equation modeling. Journal of the academy of marketing science, 43(1), 115-135.

Hilgert, M. A., Hogarth, J. M., \& Beverly, S. G. (2003). Household financial management: The connection between knowledge and behavior. Fed. Res. Bull., 89, 309.

House Hold Integrated Economic Survey [HIES] (2015-2016). House Hold Integrated Economic Survey of Pakistan. Retrieved from http://www.pbs.gov.pk/content/householdintegrated-economic-survey-hies-2015-16.

Hussain, I., \& Sajjad, S. (2016). Significance of Financial Literacy and Its Implications: A Discussion. Journal of Business Strategies, 10(2), 141-154

Huston, S. J. (2012). Financial literacy and the cost of borrowing. International Journal of Consumer Studies, 36(5), 566-572.

Isomidinova, G., \& Singh, J. S. K. (2017). Determinants of financial literacy: a quantitative study among young students in Tashkent, Uzbekistan. Electronic Journal of Business \& Management, 2(1), 61-75.

Jamal, A. A. A., Ramlan, W. K., Karim, M. A., \& Osman, Z. (2015). The effects of social influence and financial literacy on

savings behavior: A study on students of higher learning institutions in Kota Kinabalu, Sabah. International Journal of Business and Social Science, 6(11), 110-119.

Jamal, N., Hanif, M., \& Mushtaq, M, (2014). Interval regression model for family income and saving: World Applied Sciences Journal 32(11), 2276-2284

Jappelli, T., \& Padula, M. (2013). Investment in financial literacy and saving decisions. Journal of Banking \& Finance, 37(8), 2779-2792. 
Jorgensen, B. L., \& Savla, J. (2010). Financial literacy of young adults: The importance of parental socialization. Family Relations, 59(4), 465-478.

Jorgensen, B. L., Rappleyea, D. L., Schweichler, J. T., Fang, X., \& Moran, M. E. (2016). The financial behavior of emerging adults: A family financial socialization approach. Journal of Family and Economic Issues, 38(1), 57-69.

Joukes, E., Cornet, R., de Bruijne, M. C., de Keizer, N. F., \& Abu-Hanna, A. (2018). Development and validation of a model for the adoption of structured and standardised data recording among healthcare professionals. BMC medical informatics and decision making, 18(1)54, 1-11

Kast, F., Meier, S., \& Pomeranz, D. (2016). Saving more in groups: Field experimental evidence from Chile. Harvard Business School Working Paper 12-060.

Katona, G. (1974). Psychology and consumer economics. Journal of Consumer Research, 1-8.

Khan, T., Gill, A. R., \& Hanif, S. (2013). Determinants of private saving: A case of Pakistan. Asian Journal of Economic Modelling, 1(1), 1-7.

Kim, J., Gutter, M. S., \& Spangler, T. (2017). Review of family financial decision making: Suggestions for future research and implications for financial education. Journal of Financial Counseling and Planning, 28(2), 253-267.

Klapper, L., Lusardi, A., \& Van Oudheusden, P. (2015). Financial literacy around the world. Standard \& Poor's Ratings Services Global Financial Literacy Survey., Access mode: http://media. mhfi. com/documents/2015-Finlit_paper_17_F3_SINGLES. pdf.

Kline, R. B. (2011). Principles and practice of structural equation modeling. New York: Guilford Press.

Kretschmer, T., \& Pike, A. (2010). Links between nonshared friendship experiences and adolescent siblings' differences in aspirations. Journal of Adolescence, 33(1), 101-110.

Lee, J.M. and Hanna, S.D. (2015), "Savings goals and saving behavior from a perspective of Maslow's hierarchy of needs", Journal of Financial Counseling and Planning, 26(2)129147.

Lieber, E. M., \& Skimmyhorn, W. (2018). Peer effects in financial decision-making. Journal of Public Economics, 163, 37-59.

Lin, J. T., Bumcrot, C., Ulicny, T., Lusardi, A., Mottola, G., Kieffer, C., \& Walsh, G. (2016). Financial capability in the United States. Finra Investor Education Foundation

Longobardi, S., Pagliuca, M. M., \& Regoli, A. (2017). Family background and financial literacy of Italian students: the mediating role of attitudes and motivations. Economics Bulletin, 37(4), 2585-2594.

Lopera, M. A., \& Marchand, S. (2018). Peer effects and risk-taking among entrepreneurs: Labin-the-field evidence. Journal of Economic Behavior \& Organization, 150, 182-201.

Lusardi, A. (2008). Financial Literacy: An Essential Tool for Informed Consumer Choice? National Bureau of Economic Research Working Paper Series No. 14084.

Lusardi, A. $\left(2008^{\mathrm{b}}\right)$. Household Saving Behavior: The Role of Financial Literacy, Information, and Financial Education Programs. National Bureau of Economic Research Working Paper Series No. 13824

Lusardi, A. (2009). The importance of financial literacy. National Bureau of Economic Research Reporters, 2, 13-16.

Lusardi, A., \& Mitchell, O. (2006). Financial Literacy and Planning Implications for Retirement Wellbeing. Working Paper no. 1. Wharton School, University of Pennsylvania, Pension Research Council. 
Lusardi, A., \& Mitchell, O. (2008). Planning and Financial Literacy: How Do Women Fare? American Economic Review, 98(2), 413-417.

Lusardi, A., \& Mitchell, O. (2008). Planning and Financial Literacy: How Do Women Fare? American Economic Review, 98(2), 413-417.

Lusardi, A., \& Mitchell, O. S. (2007). Baby boomer retirement security: The roles of planning, financial literacy, and housing wealth. Journal of monetary Economics, 54(1), 205-224.

Lusardi, A., \& Mitchell, O. S. (2009). Financial literacy: Evidence and implications for financial education. Trends and Issues. TIAA-CREF Institute.

Lusardi, A., \& Mitchell, O. S. (2011 $\left.{ }^{\mathrm{a}}\right)$. Financial literacy around the world: an overview. Journal of Pension Economics \& Finance, 10(4), 497-508.

Lusardi, A., \& Mitchell, O. S. $\left(2011^{\mathrm{b}}\right)$. Financial Literacy and Retirement Planning in the United States. CeRP Working Paper (107), 1-27.

Lusardi, A., \& Mitchell, O. S. $\left(2011^{\mathrm{C}}\right)$. Financial literacy and planning: Implications for retirement wellbeing (No. w17078). National Bureau of Economic Research.

Lusardi, A., \& Mitchell, O. S. (2014). The economic importance of financial literacy: Theory and evidence. Journal of Economic Literature, 52(1), 5-44.

Lusardi, A., \& Scheresberg, C. D. B. (2013). Financial literacy and high-cost borrowing in the United States. National Bureau of Economic Research Working Paper (No. w18969).

Lusardi, A., Mitchell, O. S., \& Curto, V. (2010). Financial literacy among the young. Journal of Consumer Affairs, 44(2), 358-380.

Macrae, C. N., Mitchell, J. P., Golubickis, M., Ho, N. S., Sherlock, R., Parlongo, R., \& Christian, B. M. (2016). Saving for your future self: The role of imaginary experiences. Self and Identity, 1-15

Mahdzan, N. S., \& Tabiani, S. (2013). The Impact of Financial Literacy on Individual Saving: An Exploratory Study in the Malaysian

context. Transformations in Bchenusiness and Economics, 12(1).

Mancebón, M. J., Ximénez-de-Embún, D. P., Mediavilla, M., \& Gómez-Sancho, J. M. (2019). Factors that influence the financial literacy of young Spanish consumers. International Journal of Consumer Studies, 43(2), 227-235.

Mandell, L. (2008). Financial Literacy of High School Students. In Handbook of Consumer Finance Research, 163-164 edited by J. J. Xiao. New York: Springer. Retrieved June 16, 2018 from: https://link.springer.com/chapter/10.1007\%2F978-0-387-757346_10

Mansoor, A., \& Khattak, S. K. (2014). Analyzing the determinants of household's saving behavior in Pakistan: A theoretical approach. City University Research Journal, 122-130

Masche, J. G. (2010). Explanation of normative declines in parents' knowledge about their adolescent children. Journal of Adolescence, 33(2), 271-284.

Metcalfe, J., \& Mischel, W. (1999). A hot/cool-system analysis of delay of gratification: dynamics of willpower. Psychological review, 106(1), 3.

Mischel, W., Shoda, Y., \& Rodriguez, M. I. (1989). Delay of gratification in children. Science, 244(4907), 933-938.

Mitchell, O. S., \& Lusardi, A. (2015). Financial literacy and economic outcomes: Evidence and policy implications. The Journal of Retirement, 3(1), 107-114

Mitchell, O. S., Lusardi, A., \& Curto, V. (2009). Financial literacy among the young: Evidence and implications for consumer policy. Pension Research Council WP, 9.

Modigliani, F. (1986). Life cycle, individual thrift, and the wealth of nations. The American Economic Review, 76, 297-313. 
Moschis, G. P. (1985). The role of family communication in consumer socialization of children and adolescents. Journal of consumer research, 11(4), 898-913.

Mpaata, E., Koskei, N., \& Saina, E. (2020). Financial Literacy and Saving Behavior among Micro and Small Enterprise Owners in Kampala, Uganda: The Moderating Role of Social Influence. Journal of Economics, Finance and Accounting Studies, 22-34.

Mugerman, Y., Sade, O., \& Shayo, M. (2014). Long term savings decisions: Financial reform, peer effects and ethnicity. Journal of Economic Behavior \& Organization, 106, 235-253.

OECD. (2005), Improving Financial Literacy: Analysis of Issues and Policies, OECD publication. ISBN 92-64-01256-7 - (C) OECD 2005

Okudaira, H., Kinari, Y., Mizutani, N., Ohtake, F., \& Kawaguchi, A. (2015). Older sisters and younger brothers: The impact of siblings on preference for competition. Personality and Individual Differences, 82, 81-89.

Peng, T. C. M., Bartholomae, S., Fox, J. J., \& Cravener, G. (2007). The impact of personal finance education delivered in high school and college courses. Journal of family and economic issues, 28(2), 265-284.

Potrich, A. C. G., Vieira, K. M., \& Kirch, G. (2018). How well do women do when it comes to financial literacy? Proposition of an indicator and analysis of gender differences. Journal of Behavioral and Experimental Finance, 17, 28-41.

Qureshi, J. A., Farooqui, S. J., \& Qureshi, M. A. (2016). Johnny Rockets Pakistan's Strategic Mistakes and Opportunity in a Growing Market. International Journal of Experiential Learning \& Case Studies, 1(2), 29-50.

Rha, J. Y., Montalto, C. P., \& Hanna, S. D. (2006). The effect of self-control mechanisms on household saving behavior Journal of Financial Counseling and Planning 17(2). 3-16

Ribeiro, R. B., Fonseca, J. R., \& Soares, I. (2018). Spend as I say, not as I do: Children, families and household consumption in different socio-economic contexts. International journal of consumer studies, 42(5), 566-582. Retrieved from https://onlinelibrary.wiley.com/doi/abs/10.1111/ijcs.12476 dated: 22/05/2020

Robertson-Rose, L. (2019). "Because My Father Told Me To": Exploratory Insights into Parental Influence on the Retirement Savings Behavior of Adult Children. Journal of Family and Economic Issues, 1-13.

Robertson-Rose, L. (2020). "Because my father told me to": Exploratory insights into parental influence on the retirement savings behavior of adult children. Journal of Family and Economic Issues, 41(2), 364-376.

Saqib, S., Panezai, S., Ullah, H., Ali, U., \& Usman, H. (2016). Determinants of household savings in rural and urban areas: The case of chitral district, Pakistan. International Journal of Academic Research in Business and Social Sciences, 6(3), 54-64.

Shim, S., Barber, B. L., Card, N. A., Xiao, J. J., \& Serido, J. (2010). Financial socialization of firstyear college students: The roles of parents, work, and education. Journal of youth and adolescence, 39(12), 1457-1470.

Shim, S., Serido, J., Bosch, L., \& Tang, C. (2013). Financial identity-processing styles among young adults: A longitudinal study of socialization factors and consequences for financial capabilities. Journal of Consumer Affairs, 47(1), 128-152.

Sohn, S. H., Joo, S. H., Grable, J. E., Lee, S., \& Kim, M. (2012). Adolescents' financial literacy: The role of financial socialization agents, financial experiences, and money attitudes in shaping financial literacy among South Korean youth. Journal of Adolescence, 35(4), 969-980. 
Subhani, M. I., Hasan, S. A., \& Osman, A. (2012). Spending patterns in youth: American Journal of Scientific Research, 54(2012), 140-143

Subhani, M. I., Hasan, S. A., \& Osman, A. (2012). Spending patterns in youth: American Journal of Scientific Research, 54(2012), 140-143

Teo, T. S. H., Srivastava, S. C., \& Jiang, L. (2008). Trust and electronic government success: an empirical study. Journal of Management Information Systems, 25(3), 99-132.

Trombitas, K. (2011). Financial capability now: why college students can't wait: Action plan for developing a campus financial education program. Retrieved from: https://www.cgsnet.org/ckfinder/userfiles/files/Inceptia_FinancialCapability_Whitepa per.pdf, dated: 14.10.2019, 1-12

Wärneryd, K. E. (1999). The psychology of saving. Books.

Xiao, J. J., \& Porto, N. (2017). Financial education and financial satisfaction: Financial literacy, behavior, and capability as mediators. International Journal of Bank Marketing, 35(5), 805-817.

Xiao, J. J., Tang, C., Serido, J., \& Shim, S. (2011). Antecedents and consequences of risky credit behavior among college students: Application and extension of the theory of planned behavior. Journal of Public Policy \& Marketing, 30(2), 239-245.

Yahya, F., Zafar, R., \& Shafiq, S. (2013). Trend of fast food consumption and its effect on Pakistani society. Food Science and Quality Management, 11, 1-8.

Yahya, F., Zafar, R., \& Shafiq, S. (2013). Trend of fast food consumption and its effect on Pakistani society. Food Science and Quality Management, 11, 1-8.

Zaleskiewicz, T., Gasiorowska, A., \& Kesebir, P. (2013). Saving can save from death anxiety: Mortality salience and financial decision-making. PloS One, 8(11), e79407.

Zhang, L. (2009). An exchange theory of money and self-esteem in decision making. Review of General Psychology, 13, 66-76. http://dx .doi.org/10.1037/a0014225

Zhang, L., \& Baumeister, R. F. (2006). Your money or your self-esteem: Threatened egotism promotes costly entrapment in losing endeavors. Personality and Social Psychology Bulletin, 32, 881-893. http://dx.doi.org/10.1177/0146167206287120. 